\title{
Pemberdayaan Usaha Mikro Kecil dan Menengah (UMKM) Ikatan Makanan Olahan (IMO) dalam upaya legalitas usaha
}

\author{
Heri Kusmanto*, Warjio, \& Evi Yunita Kurniaty \\ Universitas Sumatera Utara \\ * herikusmanto@usu.ac.id
}

\begin{abstract}
Abstrak. Usaha Mikro Kecil dan Menengah (UMKM) merupakan salah satu entitas pelaku ekonomi yang eksistensinya mendominasi terhadap perekonomian bangsa, baik diperkotaan maupun pedesaan, termasuk usaha yang bergerak di sektor kuliner. Dalam pengabdian masyarakat ini akan memberdayakan UMKM Ikatan Makanan Olahan (IMO). Pelaku usaha kecil disarankan untuk bergabung dengan Ikatan Makanan/Minuman Olahan (IMO), dengan tujuan semua pelaku usaha makanan/minuman dapat teridentifikasi, yang kemudian akan mudah berkoordinasi untuk menampung aspirasi pelaku UKM seperti mengetahui sumber daya manusia, peralatan, kualitas produk atau pemasaran sesuai dengan kriteria standarisasi. Memenuhi standarisasi termasuk untuk melengkapi legalitas usaha. Pelaku usaha kecil yang tergabung didalam IMO menghadapi berbagai permasalahan dalam hal perijinan dan legalisasi usaha. Memiliki izin usaha bagi masyarakat sangat penting, namun terkadang tidak sedikiti masyarakat yang tidak mau untuk mengurus izin usahanya dikarenakan kurangnya pengetahuan, keterbatasan data, dan lain-lain. Melalui kegiatan pengabdian ini, tujuan dan target yang ingin dicapai dalam kegiatan pengabdian adalah adanya legalisasi usaha bagi para pelaku usaha di dalam Ikatan Makanan Olahan (IMO). Dengan memiliki legalitas usaha, para pelaku usaha yang tergabung dalam IMO diharapkan mampu bersaing dalam era pasar bebas. Metode yang digunakan dalam kegiatan pengabdian ini, dilakukan dalam bentuk penyuluhan, pelatihan dan pendampingan dalam pengurusan legalitas usaha.
\end{abstract}

Kata kunci: legalitas usaha; pemberdayaan; UMKM

Abstract. Micro, Small and Medium Enterprises (MSMEs) are one of the entities of economic actors whose existence dominates the nation's economy, both in urban and rural areas, including businesses engaged in the culinary sector. In community service, it will empower MSME Processed Food Association (IMO). Small business actors are advised to join the Processed Food/Beverage Association (IMO), with the aim of identifying all food/beverage businesses, which will then be easy to coordinate to accommodate the aspirations of SMEs such as knowing human resources, equipment, product quality or marketing accordingly with standardization criteria. Meet standardization, including to complete business legality. Small business actors who are members of IMO face various problems in terms of licensing and business legalization. Having a business license for the community is very important, but sometimes not a few people who do not want to take care of their business licenses due to lack of knowledge, limited data, and others. Through this service activity, the goals and targets to be achieved in the service activities are the legalization of business for business actors within the Processed Food Association (IMO). By having business legality, business people who are members of the IMO are expected to be able to compete in the free market era. The method used in this service activity is carried out in the form of counseling, training and assistance in managing business legality.

Keywords: business legality; empowerment; MSME

To cite this article: Kusmanto, H., Warjio, \& E. Y. Kurniaty. 2019. Pemberdayaan Usaha Mikro Kecil dan Menengah (UMKM) Ikatan Makanan Olahan (IMO) dalam upaya legalitas usaha. Unri Conference Series: Community Engagement 1: 577-583 https://doi.org/10.31258/unricsce.1.577-583

(C) 2019 Authors

Peer-review under responsibility of the organizing committee of Seminar Nasional Pemberdayaan Masyarakat 2019 


\section{PENDAHULUAN}

Usaha Mikro Kecil dan Menengah (UMKM) diIndonesia tetap eksis dan berkembang meski terjadi krisis ekonomi yang telah melanda negeri ini sejak tahun 1997. Hingga tahun 2011 UMKM mampu memberikan andil besar terhadap penerimaan negara dengan menyumbang $61,9 \%$ pemasukan produk domestik bruto (PDB) melalui pembayaran pajak, yang diuraikan sebagai berikut: sektor usaha mikro menyumbang 36,28\% PDB, sector usaha kecil 10,9\%, dan sektor usaha menengah 14,7\% melalui pembayaran pajak (BPS, 2011).

Sementara itu, sektor usaha besar hanya menyumbang 38,1\% PDB melalui pembayaran pajak (BPS, 2011). Menurut Urata (2000), peran UMKM dilihat dari kedudukannya yaitu sebagai pemeran utama dalam kegiatan ekonomi di berbagai sektor, seperti penyedia lapangan kerja terbesar, berperan dalam hal pengembangan kegiatan ekonomi daerah dan pemberdayaan masyarakat, pencipta pasar baru dan inovasi, dan untuk UMKM yang sudah mampu melakukan perdagangan internasional UMKM tersebut tentu mampu memberikan sumbangan dalam menjaga neraca pembayaran melalui sumbangannya dalam menghasilkan ekspor.

Di tingkat daerah khususnya kota Medan, dapat melihat bahwa secara umum pertumbuhan perekonomian kota Medan tidak terlepas dari kontribusi UMKM. Hal ini dapat dilihat dari jumlah UMKM-nya yang cukup banyak, dengan jumlah lebih kurang 242.890 unit UMKM yang terdiri dari jenis usaha perdagangan jasa, industri kerajinan dan aneka usaha lainnya, dimana kelembagaannya belum tertata secara maksimal baik itu soal perizinan maupun aspek legalitasnya sehingga jumlah UMKM di Kota Medan masih belum pasti. Adapun jenis-jenis UMKM yang ada di Kota Medan yaitu usaha dibidang kuliner, jasa percetakan, pembuatan kerajinan tangan dan sebagainya (data Disperindag Kota Medan).

Untuk UMKM di bidang kuliner yaitu makanan olahan di Sumatera Utara membentuk komunitas ikatan makanan olahan atau yang disingkat IMO. Dengan adanya IMO membantu mendata dan mengindentifikasikan usaha-usaha kuliner yang ada. Ini sebagai upaya untuk memetakan kelemahannya, sekaligus untuk mendorong agar bisa bersaing dengan produk luar.

Dinas Perindustrian dan Perdagangan Provinsi Sumatera Utara terus menghimbau agar pelaku usaha makanan dan minuman bergabung dengan Ikatan Makanan/Minuman olahan (IMO). Sebab pihak Disperindag akan berkoordinasi dengan komunitas ini untuk menampung aspirasi pelaku UKM di Sumatera Utara. Dari IMO, Disperindag dimintai saran dan masukan, apa yang menjadi kendala. Apakah sumber daya manusia, peralatan, kualitas produk atau pemasaran. Tujuannya untuk menghasilkan produk yang berkualitas dan berstandar dan memenuhi standarisasi.

Berbicara dengan standarisasi maka berbicara dengan legalitas usaha. Izin juga bisa didefinisikan sebagai bentuk persetujuan atau pemberian izin dari pihak berwenang atas penyelenggaraan suatu kegiatan usaha oleh seseorang penngusaha atau suatu perusahaan.bagi pemerintah pengertian usaha dagang adalah suatu alat atau sarana untuk membina, mengarahkan, mengawasi dan menertibkan izin-izin usaha perdagangan. Agar kegiatan usaha lancar, maka setiap pengusaha wajib untuk mengurus dan memiliki izin usaha dari instansi pemerintah yang sesuai dengan bidangnya (Peraturan Menteri Perdagangan RI Nomor:46/-DAG/PER/9 tentang penerbitan Izin Usaha).

Oleh sebab itu dalam pengabdian ini akan memberdayakan Usaha Mikro Kecil dan Menengah (UMKM) yang bergerak dalam bidang usaha makanan olahan yaitu ikatan makanan/minuman olahan (IMO). Secara garis besar permasalahan Mitra yaitu tidak adanya legalitas usaha para pelaku-pelaku UKM di IMO, tidak adanya standarisasi produk karena kurangnya pengetahuan tentang kewirausahaan, termasuk manajemen usaha dan promosi di media digital. Untuk pendataan keanggotaan di Ikatan makanan olahan masih ada kesulitan karena tidak adanya kesatuan fungsi perekrutan/pendataan anggota, masih banyak usaha makanan olahan yang belum masuk menjadi anggota IMO dan belum mengetahui manfaat dari masuk dalam keanggotaan IMO.

Ikatan Makanan/Minuman Oalahan (IMO) terbentuk dari 27 April 2000. Visi terwujudnya organisasi IMO, Usaha Mikro Kecil dan Menengah menjadi lembaga yang tumbuh dan berkembang secara sehat, tangguh dan mandiri dengan tingkat daya saing yang tinggi sehingga dapat berperan sebagai pelaku utama dala perekonomian Provinsi Sumatera Utara yang bertumpu pada mekanisme yang berkeadilan dan menjadi fasilitator yang memiliki kompetensi tinggi.

Misi IMO yaitu: berperan aktif dalam meningkatkan perekonomian daerah, meningkatkan taraf hidup masyarakat untuk lebih sejahtera, makmur, aman dan sentosa, senantiasa meningkatkan keahlian dan keterampilan hingga menjadi pelaku usaha yang profesional dan dapat menghasilkan produk-produk yang berkualitas, bergizi dan menyehatkan, sinergi dalam menciptakan pasar hingga mampu bersaing, tangguh dan mandiri. 
Potensi dan Peluang usaha yang didapat dari IMO adalah dengan tergabungnya para pelaku usaha dalam komunitas Ikatan makanan olahan sebagai upaya peningkatan daya saing UKM di Sumatera Utara. Lebih dari itu, diharapkan produk-produk yang dihasilkan tidak kalah bersaing ditengah masyarakat ekonomi Asean (MEA). Jangan pula untuk dikonsumsi di medan atau Sumatera Utara tetapi juga masuk produk luar negeri yang mempunyai kualitas yang lebih baik dari makanan olahan. Persaingan terhadap produk luar negeri maka diperlukan legalitas usaha, standarisasi produk, dan pemasaran yang baik.

Menurut Dipta dalam Julita dan Sari (2015) menyampaikan apabila Indonesia tidak mendorong daya saing dan nilai tambah atas barang/produk yang diproduksi, maka Indonesia dapat kehilangan perannya di kawasan dan menjadi objek kemajuan pembangunan di kawasan tanpa memperoleh keutungan yang maksimal. Oleh karena itu, program kebijakan penguatan daya saing telah mendapatkan perhatian khusus dari pemerintah, antara lain penguatan UKM nasional. Hal tersebut penting untuk memfasilitasi UMKM nasional yang berdaya saing tinggi, inovatif, dan kreatif, serta mampu melakukan perluasan pasar dari Komunitas Ekonomi ASEAN.

Aspek produksi dan manajemen usaha yangada dalam Ikatan Makanan Olahan (IMO) adalah usaha rumahan yang mengelola bahan baku menjadi olahan makanan, seperti olahan ubi, olahan daging, olahan ayam, olahan berbagai buah-buahan. Juga ada olahan produk yang sudah jadi namun diberi kreasi menjadi makanan yang lebih enak, seperti olahan kurma, olahan coklat, dan lain-lain. UMKM makanan. Minuman olahan masih dihadapkan pada berbagai persoalan sehingga menyebabkan lemahnya daya saing terhadap produk impor.

Persoalan utama yang dihadapi UMKM, antara lain keterbatasan infrastruktur dan akses pemerintah terkait dengan perizinan dan birokrasi serta tingginya tingkat pungutan. Dengan segala persoalan yang ada, potensi UMKM yang besar itu menjadi terhambat. Meskipun UMKM dikatakan mampu bertahan dari adanya krisis global namun pada kenyataannya permasalahan-permasalahan yang dihadapi sangat banyak dan lebih berat. Hal itu dikarenakan selain dipengaruhi secara tidak langsung krisis global tadi, UMKM harus pula menghadapi persoalan domestik yang tidak kunjung terselesaikan seperti masalah upah buruh, ketenagakerjaan dan pungutan liar, modal, promosi yang minim, peralatan yang tidak memadai, dan lain-lain.

Kuncoro (2009) mengungkapkan bahwa masalah dasar yang dihadapi UMKM adalah kelemahan dalam memperoleh peluang pasar dan memperbesar pangsa pasar, kelemahan dalam struktur permodalan, kelemahan dalam bidang organisasi dan manajemen sumber daya manusia, keterbatasan jaringan usaha kerja sama antar pengusaha kecil, iklim usaha yang kurang kondusif, pembinaan yang kurang terpadu serta kurangnya kepercayaan masyarakat dan kepedulian terhadap usaha kecil.

Pembinaan yang kurang terpadu dan kepeduliaan terhadap usaha kecil dapat dilihat dari tidak dimilikinya legalitas usaha yang harusnya mereka wajib sudah miliki. Upaya-upaya yang dilakukan untuk memberdayakan UMKM Ikatan Makanan Olahan (IMO) dalam hal legalitas usaha belum pernah dilakukan. Oleh karena itu tujuan pengabdian masyarakat ini adalah untuk memberikan pelatihan, peyuluhan dan pendampingan kepada para pelaku usaha makanan olahan agar mendapatkan legalitas usaha, baik itu Merek Dagang, SIUP (Surat Izin Usaha Perdagangan), IUMK (Izin Usaha Mikro Kecil), Sertifikat Halal MUI, dan Izin Depkes.

\section{MASALAH}

Dari analisis permasalahan terdapat banyak permasalahan yang dihadapi UMKM Ikatan Makanan Olahan (Mitra), namun tim pengabdian mengelompokan kepada 2 (dua) hal yaitu:

1. Legalitas Usaha: bentuk persetujuan atau pemberian izin dari pihak berwenang atas penyelenggaraan suatu kegiatan usaha, termasuk usaha rumahan/kecil. Bagi pemerintah pengertian usaha dagang adalah suatu alat atau sarana untuk membina, mengarahkan, mengawasi dan menertibkan izin-izin usaha perdagangan. Agar kegiatan usaha lancar dan mampu bersaing dalam ranah lokal dan internasional, maka setiap pelaku usaha IMO wajib untuk mengurus dan memiliki izin usaha dari instansi pemerintah yang sesuai dengan bidangnya. Pelaku usaha IMO mendapat banyak kesulitan dalam pengurusan legalitas usaha, seperti Surat Ijin Usaha Mikro Kecil (IUMK), Merk Dagang, SIUP (Surat Izin Usaha Perdagangan) dan pengurusan sertifikasi Halal. Adapun kendala yang didapati yaitu kurang pengetahuan administrasi, tidak mengenal macam-macam legalitas usaha, tidak mengetahui manfaat dari legalitas usaha, dan kurangnya dana untuk mengajukan legalitas usaha.

2. Kelembagaan: sulitnya pendataan anggota makanan olahan dan kurangnya informasi tentang manfaat ikut serta dalam Ilatan Makanan Olahan. Selain itu juga koordinasi di dalam organisasi masih lemah, sehingga sering informasi tidak dapat diketahui sepenuhnya kepada anggota-anggota. Informasi 
tersebut seperti adanya pameran, pelatihan yang dilakukan, informasi mengenai adanya bantuan dari pemerintah, dan lain sebagainya.

\section{METODE}

Metode pelaksanaan pengabdian masyarakat pemberdayaan UMKM Makanan Olahan dirancang secara komprehensif dan proporsional sesuai persentase efektifitas yang akan dicapai, dimana Tim pelaksana pihak perguruan tinggi akan lebih banyak berperan sebagai fasilitator, bukan semata penceramah. Metode yang digunakan adalah:

\section{In-class discussion}

Tujuannya untuk menumbuhkan kepekaan (awareness) dan membangun kerangka berfikir (framework of thinking) terhadap pentingnya pelaku usaha untuk memiliki legalitas usaha dan mengtahui kiat-kiat untuk mendapatkan legalitas usaha.

\section{Case study}

Tujuannya untuk meningkatkan kepekaan penggiat UMKM dan masyarakat terhadap pemberdayaan UMKM dari segi legalitas usaha. Bahwa pelaku usaha yang memiliki legalitas berpeluang biss bersaing dalam ranah lokal, nasional dan internasional.

Lokasi Pengabdian di Sekretarian Ikatan Makanan Olahan (IMO) Jalan Elang Komplek KBP No. B22 Medan. Lama pengabdian adalah 6 (enam) bulan pada bulan Mei-November 2019.

Tabel 1. Penerapan Kegiatan Pengabdian kepada Masyarakat

\begin{tabular}{|c|c|c|}
\hline Langkah-langkah & Durasi Kegiatan & Kegiatan \\
\hline Persiapan & 2 minggu & $\begin{array}{l}\text { - Berangkat ke lokasi, lokasi pengabdian: Sekretariat Ikatan Makanan } \\
\text { Olahan. Jl. Elang Komplek KPB No. B22 Medan } \\
\text { - Menyediakan bahan dan materi tentang legalitas usaha dan } \\
\text { - Melembagaan } \\
\text { - Menyediakan bahan dan materi untuk kebutuhan pengabdian }\end{array}$ \\
\hline Survei Lokasi & 2 minggu & $\begin{array}{l}\text { - Observasi potensi dan keadaan Mitra } \\
\text { - Kegiatan survei meliputi melihat kebutuhan akan legalitas usaha } \\
\text { Mendengarkan keluhan para penggiat usaha berkaitan dengan } \\
\text { legalitas usaha }\end{array}$ \\
\hline $\begin{array}{c}\text { Menjalin } \\
\text { komunikasi }\end{array}$ & 1 bulan & $\begin{array}{l}\text { - Melakukan pendekatan kepada Mitra } \\
\text { - Melakukan pendekatan kepada Pemerintah dan Dinas yang terkait. } \\
\text { - } \text { kerangkum tentang permasalahan-permasalahan legalitas usaha dan } \\
\text { kelembaan }\end{array}$ \\
\hline $\begin{array}{l}\text { Mengadakan } \\
\text { pelatihan }\end{array}$ & 2 bulan & $\begin{array}{l}\text { - Pelatihan dan penyuluhan mengenai macam-macam legalitas usaha, } \\
\text { perbedaan legalitas usaha yang satu dengan yang lain, manfaat- } \\
\text { manfaat dari legalitas usaha } \\
\text { - Pelatihan dan penyuluhan tentang penguatan kelembagaan } \\
\text { - Melengkapi berkas-berkas administrasi yang diperlukan untuk } \\
\text { memenuhi syarat pembuatan legalitas usaha. }\end{array}$ \\
\hline $\begin{array}{c}\text { Melakukan } \\
\text { pendampingan }\end{array}$ & 2 bulan & $\begin{array}{l}\text { - Melakukan pendampingan secara berkala untuk melihat } \\
\text { perkembangan dalam pengurusan legalitas usaha dan perkembangan } \\
\text { organisasi Ikatan Makanan Olahan }\end{array}$ \\
\hline
\end{tabular}

Prosedur kerja diatas diterapkan untuk mendukung penyelesaian masalah Mitra melalui pendidikan, pelatihan, dan pendampingan. Pihak Mitra dan tim pelaksana akan berkumpul di Sekretariat IMO untuk melakukan pemberian materi sekaligus praktek langsung sesuai dengan permasalahan yang akan diselesaikan.

Persoalan prioritas yang disepakat bersama untuk diselesaikan selama masa pelaksanaan program pengabdian yaitu mengurus legalitas usaha dari anggota-anggota IMO yang telah melengkapi syarat, dan kelengkapan surat. Penguatan kelembagaan yaitu dengan mendata dan mengorganisir anggota-anggota makanan olahan yang sudah bergabung dan yang belum. Memberi pengetahuan tentang penguatan kelembagaan yaitu perekrutan dan manajemen organisasi. 


\section{PEMBAHASAN}

UMKM adalah singkatan dari Usaha Mikro, Kecil, dan Menengah. UMKM diatur berdasarkan UU Nomor 20 tahun 2008 tentang Usaha Mikro, Kecil, dan Menengah. Berdasarkan UU Nomor 20 tahun 2008 Usaha Mikro didefinisikan sebagai bentuk usaha produktif milik orang perorangan dan/atau badan usaha perorangan yang memenuhi kriteria Usaha Mikro sebagaimana diatur dalam Undang-Undang ini.

UMKM harus mampu menekankan kepada paradigma orientasi pasar dan daya saing untuk itu ada sejumlah prinsip dasar yang harus dipenuhi, diantaranya sebagai berikut (Tambunan, 2010): (1) Bisnis adalah tetap bisnis, jika seseorang membuka UMKM sendiri namun terpaksa tutup karena kalah bersaing, tidak perlu dibantu untuk dihidupkan kembali. (2) Hanya UMKM yang memiliki potensi pasar dan memiliki keuggulan komparatif dan kompetitif yang perlu dibantu oleh pemerintah, jadi prinsip yang berlaku adalah "picking the winners". (3) Fokus bantuan yang diberikan kepada UMKM harus pada pengembangan teknologi dan inovasi. (4) Pemberian kredit bagi UMKM tidak merupakan komponen yang paling penting. Pengalaman menunjukkan UMKM yang mulai dan atau berkembang dengan sendirinya akan didatangi oleh perbankan. (5) Bantuan pada UMKM tidak bersifat protektif, dalam konteks ini sejalan dengan prinsip yang bisa maju adalah UMKM yang mampu bersaing bebas dalam kondisi pasar non-diskriminasi.

UMKM baik itu yang berskala mikro, kecil dan menengah dianjurkan harus memiliki izin usaha. Izin usaha merupakan suatu bentuk dokumen resmi dari instansi berwenang, yang menyatakan sah/dibolehkannya seseorang atau badan untuk melakukan suatu usaha atau kegiatan tertentu. Jadi, begitu pentingnya 'ijin usaha' tersebut dalam konteks berusaha, khususnya bagi Usaha Mikro, Kecil dan Menengah (UMKM), sehingga mereka dapat terlindungi, adanya kepastian dalam berusaha dan menikmati kenyamanan serta keamanan yang patut mereka peroleh, agar dapat berkontribusi secara lebih nyata di dalam peningkatan nilai tambah produksi, penyediaan barang dan jasa kebutuhan masyarakat, penyerapan tenaga kerja dan diseminasi penumbuhan kewirausahaan.

Dalam kaitan itu, Undang-Undang Nomor 20 tahun 2008 tentang Usaha Mikro, Kecil dan Menengah (UMKM) telah diatur bahwa: Pemerintah dan Pemerintah Daerah menempatkan "perizinan usaha" sebagai salah satu aspek strategis dalam rangka penciptaan iklim usaha disamping aspek yang lain, yaitu: pendanaan; sarana dan prasarana; informasi usaha; kemitraan; kesempatan berusaha; promosi dagang; dan dukungan kelembagaan.

Ditegaskan pula pada pasal 12 UU Nomor 20/2008 tentang UMKM tersebut, bahwa aspek perizinan usaha itu ditujukan untuk:

a. menyederhanakan tata cara dan jenis perizinan usaha dengan sistem pelayanan terpadu satu pintu; dan

b. membebaskan biaya perizinan bagi Usaha Mikro dan memberikan keringanan biaya perizinan bagi Usaha Kecil.

Izin Usaha Mikro Kecil (IUMK) bisa didapat dengan mudah setelah melengkapi beberapa persyaratan seperti mengajukan izin ke kantor Camat dengan melampirkan KTP, fotokopi Kartu Keluarga dan surat keterangan dari Kepala Desa.

\section{Pentingnya Izin Usaha Bagi Pelaku UMKM}

Beberapa manfaat pentingnya izin usaha bagi UMKM, yaitu:

1. UMKM akan mendapatkan jaminan perlindungan hukum. Dengan memiliki izin usaha, dapat menjalankan operasional bisnis secara aman dan nyaman. Tidak perlu khawatir terhadap ancamanancaman lain yang kerap menimpa usaha yang tidak memiliki perizinan. Seperti penertiban maupun pembongkaran.

2. Memudahkan dalam mengembangkan usaha. Selain itu, memiliki izin usaha juga akan memudahkan dalam mengembangkan usaha Anda saat ini. Misalnya, ingin bekerja sama dengan pengusaha yang lain.

3. Membantu memudahkan pemasaran usaha. Baik dalam lingkup nasional maupun internasional atau juga memudahkan dalam melakukan ekspor dan impor produk, jika usaha yang dijalankan berupa barang.

4. Akses pembiayaan yang lebih mudah. Jika sudah memiliki surat izin usaha, akan mendapatkan kemudahan dalam melakukan peminjaman dana pada pihak bank.

5. Memperoleh pendampingan usaha dari pemerintah. Seringkali pemerintah mengadakan beberapa program pendampingan bagi para pelaku usaha kecil untuk mengajak mereka mengembangkan inovasi produk serta usahanya. Pendampingan ini bisa berupa workshop, seminar maupun penyuluhan langsung ke lokasi usaha. 
Dalam pengabdian ini lebih mengutamakan legalitas usaha Logo Halal produk Usaha Kuliner. Mempunyai sebuah logo halal pada produk usaha memang termasuk salah satu hal penting. Apalagi di negara kita yang bermayoritas agama Islam ini. Pastinya akan sangat penting sekali terutama soal makanan dan minuman.

Kementrian Agama meresmikan Badan Penyelenggara Jaminan Produk Halal (BPJPH) dimana nanti akan menjadi lembaga pemberi sertifikat halal resmi di Indonesia. Dengan adanya lembaga ini, produk-produk yang diperjualbelikan di Indonesia wajib untuk mempunyai sertifikasi halal sesuai dengan UU JPH yang akan efektif tahun 2019.

Ada tiga poin kriteria halal menurut MUI yaitu sebagai berikut:

1. Material. Maksud material disini adalah komposisi atau bahan yang dipakai produk harus memenuhi Material Safety Data Sheet, diproduksi pada fasilitas yang bebas dengan hewan haram, sampai lulus pengujian food contact standard.

2. Produk. Setelah bahan, produk luar atau kemasan juga harus memenuhi syarat seperti tidak terkontaminasi dengan najis, memiliki kode produksi, terdaftar dalam MUI, sampai desain maupun bentuknya tidak mengarah kepada hewan haram.

3. Penyimpanan dan Pengiriman. Tempat penyimpanan dan pengiriman juga harus dipastikan kehalalannya baik dari lokasi penyimpanan sampai cara pengirimannya.

Keuntungan Logo Halal pada Produk Usaha Kuliner

1. Produk Usaha akan Menjalani Uji Coba yang Rutin. Ketentuan megajukan sertifikasi halal adalah mempunyai divisi atau departemen yang berurusan dalam mengawasi dalam proses produksi sampai selesai produksi. Untuk itu akan ada tes uji coba secara rutin tergantung dengan jadwal yang telah disetujui.

2. Konsumen akan Merasa Tenang, Aman dan Nyaman dengan Mengkonsumsi Produk Usaha. Kepercayaan adalah modal utama bagi sebuah usaha. Logo halal ini adalah salah satunya. Inilah yang menjadi tujuan utama dari pengadaan logo halal pada kemasan produk usaha. Konsumen akan merasa lebih tenang, aman, serta nyaman karena sudah membeli produk yang aman bagi mereka.

3. Mendapatkan Citra Positif dari Masyarakat. Selain kepercayaan dengan logo halal yang tertera, seorang produsen juga akan mendapatkan citra positif dari masyarakat. Konsumen akan semakin merekomendasi produk pelaku usaha sebagai produk yang aman untuk digunakan karena telah mempunyai logo halal.

4. Produk Usaha Kuliner dapat Bersaing dengan Produk Luar Negeri. Dengan mengajukan sertifikasi halal serta mendapatkan logo halalnya secara resmi maka produk akan lebih dipilih dari pada produk luar negeri yang masih belum jelas kualitasnya.

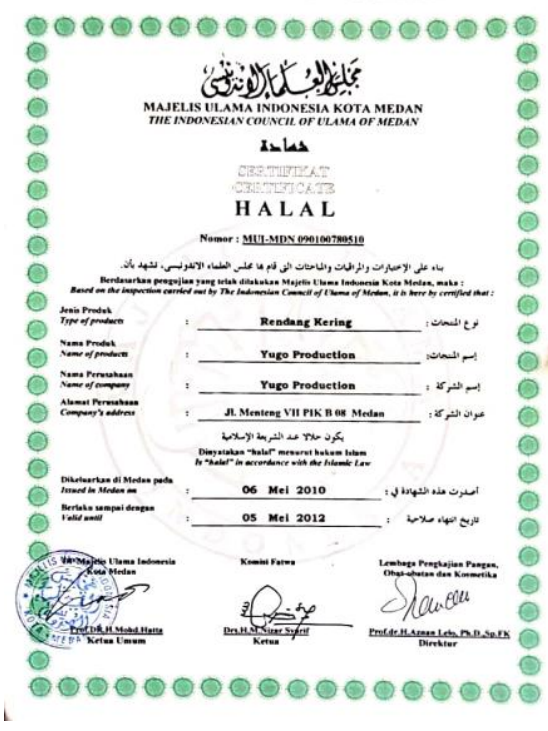

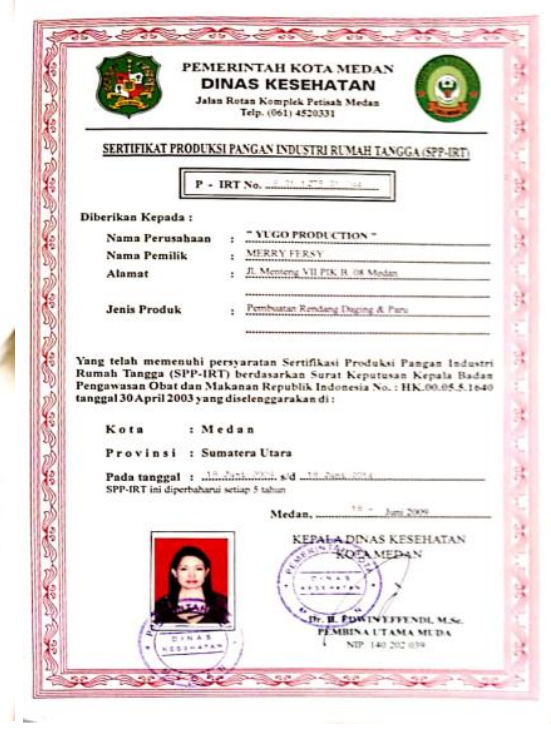

Gambar 1. Legalitas Usaha

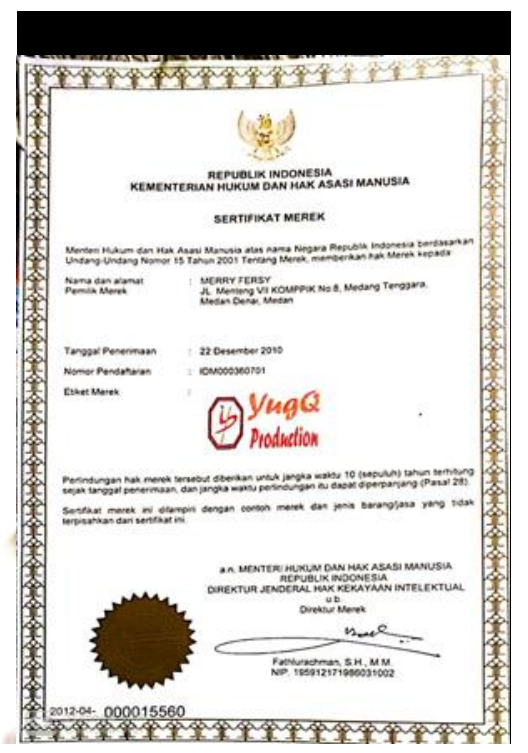

Gambar 1 adalah legalitas usaha yang sudah dimiliki salah satu anggota dari Ikatan Makanan Olahan, yaitu sertifikasi halal, Surat perizinan dari Dinas Kesehatan dan Sertifikasi Merek Dagang. Usaha makanan olahan rendang Yugo ini salah satu pelaku usaha yang sudah memiliki legalitas usaha yang jelas, walaupun sekarang 
legalitas usaha itu sudah ada yang expired atau kadaluarsa. Harus diperbaharui dan ditingkatkan agar usaha ini tidak jalan ditempat atau malah tertinggal dari produk usaha sejenis.

Kesulitan dalam pelaksanaan kegiatan saat mengurus legalitas usaha dan penguatan kelembagaan, yaitu:

1. pelaku birokrasi di lapangan masih terlihat kaku, dari meja ke meja harus dilewati. Sehingga, proses pengurusan menjadi lama dan pelaku usaha akhirnya enggan mengurus perizinan.

2. Banyak dari mereka yang kekurangan waktu untuk mengajukan permohonan izin karena waktunya sebagian besar digunakan untuk menjalankan usaha.

3. Keterbatasan dana, karena beberapa legalitas usaha harus mengeluarkan biaya untuk mendapatkannya.

4. terjadinya konflik-konflik internal di IMO menjadi hambatan tersendiri dalam upaya peningkatan performa organisasi.

\section{KESIMPULAN}

Dalam kegiatan pengabdian ini, tim pelaksana telah melakukan penyuluhan, pelatihan dan pendampingan kepada pelaku usaha UMKM Ikatan Makanan Olahan tentang legalitas usaha dan penguatan kelembagaan. Adapun yang menjadi fokus yaitu kesadaran bagi pelaku usaha untuk mengurus legaitas usaha, membuka pengetahuan tentang macam-macam dan manfaat legalitas usaha.

Agar kedepannya bisa berjalan dengan baik, maka pelaku usaha harus terus diberikan sosialisasi dan pendampingan dari pemerintah terkait dalam pengurusan legalitas usaha. Mengingat ada beberapa perubahan peraturan terkait legalitas usaha dan persaingan semakin ketat di era pasar bebas ini.

Rekomendasi kedepannya agar pemerintah terus melakukan sosialisasi dalam pengurusan legalitas usaha. Selain itu dalam menata dan membuat kemasan yang lebih menarik juga perlu dilakukan. Dalam pengabdian selanjutnya tim pelaksana ingin lebih memfokuskan kepada kelengkapan legalitas usaha dan perbaikan kemasan yang lebih higienis.

Untuk mengatasi masalah legalitas usaha pemerintah telah menetapkan Peraturan Presiden Nomor 98 tahun 2014 tentang perizinan untuk usaha mikro dan kecil yang bertujuan untuk memberikan kepastian hukum dan sarana pemberdayaan bagi Pelaku Usaha Mikro dan Kecil (PUMK) dalam mengembangkan usahanya. Selain itu, dalam pengurusan legalitas usaha setelah keluar PERPRES menjadi lebih sederhana, mudah, dan cepat sehingga menguntungkan bagi pelaku usaha. Diharapkan produsen mendapatkan banyak keuntungan dan kemudahan setelah dikeluarkannya kebijakan pemerintah ini.

\section{UCAPAN TERIMA KASIH}

Terima kasih kami ucapkan kepada Lembaga Pengabdian USU (LPM USU) yang telah memfasilitasi kegiatan pengabdian ini. Ini merupakan luaran dari pengabdian masyarakat yang berjudul Pemberdayaan UMKM Ikatan Makanan Olahan (IMO) Dalam Upaya Legalitas Usaha, Penguatan Kelembagaan dan Kewirausahaan yang mendapat pendanaan Non PNBP USU T.A. 2019.

\section{DAFTAR PUSTAKA}

Badan Pusat Statistik. 2011. Berita Resmi Statistik UKM. http://www.scribd.com/doc/16888581/Berita-Resmi-StatistikUkm

Badan Pusat Statistik. 2011. Produk Domestik Bruto. http://www.bps.go.id/index.php?news=730

Kuncoro, M. 2009. Ekonomi Indonesia: Dinamika Lingkungan Bisnis di Tengah Krisis Global. Yogyakarta: UPP STIM YKPN.

Peraturan Menteri Perdagangan RI Nomor:46/-DAG/PER/9 tentang penerbitan Izin Usaha, Jakarta 2009.

Republik Indonesia. 2008. Undang-Undang No. 20 Tahun 2008 tentang Usaha Mikro, Kecil, dan Menengah. Jakarta: Sekretariat Negara

Tambunan, T. 2010 Center for Industry, SME and Business Competition Studies. Jakarta, Indonesia: Trisakti University. 